Review

\title{
Exploring miRNA-Associated Signatures with Diagnostic Relevance in Glioblastoma Multiforme and Breast Cancer Patients
}

\author{
Véronique C. LeBlanc and Pier Jr Morin* \\ Department of Chemistry and Biochemistry, Université de Moncton, 18 Antonine-Maillet avenue, \\ Moncton, NB E1A 3E9, Canada; E-Mail: ev16741@umoncton.ca \\ * Author to whom correspondence should be addressed; E-Mail: pier.morin@umoncton.ca; \\ Tel.: +506-858-4355; Fax: +506-858-4541.
}

Academic Editors: Takahiro Ochiya and Ryou-u Takahashi

Received: 30 June 2015 / Accepted: 4 August 2015 / Published: 14 August 2015

\begin{abstract}
The growing attention that non-coding RNAs have attracted in the field of cancer research in recent years is undeniable. Whether investigated as prospective therapeutic targets or prognostic indicators or diagnostic biomarkers, the clinical relevance of these molecules is starting to emerge. In addition, identification of non-coding RNAs in a plethora of body fluids has further positioned these molecules as attractive non-invasive biomarkers. This review will first provide an overview of the synthetic cascade that leads to the production of the small non-coding RNAs microRNAs (miRNAs) and presents their strengths as biomarkers of disease. Our interest will next be directed at exploring the diagnostic utility of miRNAs in two types of cancer: the brain tumor glioblastoma multiforme (GBM) and breast cancer. Finally, we will discuss additional clinical implications associated with miRNA detection as well as introduce other non-coding RNAs that have generated recent interest in the cancer research community.
\end{abstract}

Keywords: microRNAs; glioma; glioblastoma multiforme; breast cancer; cancer diagnosis; cancer therapeutics; non-coding RNAs; long non-coding RNAs 


\section{Introduction}

Tremendous effort has been dedicated in recent years to elucidating the underlying functions of non-coding RNAs, including the small microRNAs (miRNAs), in numerous types of cancer. Several studies have characterized the roles played by miRNAs in primary tumors and have positioned these molecules as significant drivers of malignancy [1-3]. Importantly, such work has put the light on miRNAs as appealing cancer biomarkers, notably due to their significant stability and their ability to reveal crucial information on tumor grade and treatment response [4-6]. With an emphasis on in vivo human studies, this review first presents the potential advantages associated with miRNAs as cancer biomarkers and subsequently discusses studies that have identified miRNAs with diagnostic relevance in two types of cancers: glioblastoma multiforme and breast carcinomas. Finally, we introduce examples of work that have assessed the usefulness of miRNAs in other, non-diagnostic, clinical applications as well as present additional non-coding RNAs with diagnostic relevance to cancer.

\section{MiRNAs: An Overview}

MiRNA biogenesis usually starts with the transcription of miRNA genes by RNA polymerase II to generate a primary miRNA transcript termed pri-miRNA [7,8]. This capped and polyadenylated structure is further processed in the nucleus by the microprocessor complex comprised of the RNase III enzyme Drosha and the cofactor DiGeorge syndrome critical region gene 8 (DGCR8) to generate a pre-miRNA that is subsequently exported to the cytoplasm via Exportin-5 [7,9-12]. The RNase III enzyme Dicer performs pre-miRNA cleavage to yield a 20-24 nucleotide duplex miRNA from which the mature miRNA sequence will associate with Argonaute and other proteins to form the miRNA-induced silencing complex (miRISC) [13,14]. MiRISC can interact, via imperfect base pairing, with the 3 '-untranslated region (3'-UTR) of transcript targets and alter their expression via translational repression or mRNA destabilization. Complementarity between the seed region of the miRNAs (nucleotides 2-8) and nucleotides of the target mRNA plays a pivotal role in target recognition and silencing [15]. Recent evidences suggest that miRNA/transcript target interaction can also occur in the 5'-UTR or within the coding region of some mRNAs [16,17].

There are multiple arguments that support the investigation of miRNAs as biomarkers for diseases. MiRNAs can notably be packaged into exosomes, small bioactive reservoirs secreted by cells, and subsequently regulate transcript targets of recipient cells [18]. Previous work has demonstrated that miRNAs secreted by cancer cells can have various effects such as increased drug resistance and transformation of target cells [19,20]. Isolation and characterization of the molecules present in exosomes for diagnostic and prognostic purposes have been performed in different types of cancer including gliomas and breast cancer [21,22], the focus of the current review. Accordingly, miRNAs are thus present in various body fluids including serum, urine and saliva, making them collectable and quantifiable via non-invasive methods [23-25]. Furthermore, miRNAs are significantly stable in a variety of biological specimens such as blood, urine and postmortem formalin-fixed paraffin-embedded (FFPE) tissues [26-28]. MiRNA isolation from these sources is thoroughly documented and their subsequent quantification can be performed with a variety of techniques such as quantitative reverse transcription polymerase chain reaction (qRT-PCR), miRNA microarrays or next-generation sequencing 
to name a few [29-31]. Finally, miRNA levels, in primary tissues and in circulating samples, have also been associated with different clinical parameters in cancer such as metastatic progression and response to chemotherapeutic agents $[32,33]$. MiRNAs thus possess a number of criteria that position them as appealing cancer biomarkers, and the subsequent sections will focus on the diagnostic potential of miRNAs in two types of cancer.

\section{Glioblastoma Multiforme and MiRNAs}

Glioblastoma multiforme (GBM) is the most aggressive and frequently diagnosed primary brain tumor [34]. This grade IV glioma is highly malignant and the prognosis for patients diagnosed with a GBM remains poor with a median survival rate between 12 to 15 months [35,36]. Standard of care consists of surgical resection of the tumor followed by a combination of radiotherapy and chemotherapy [37]. At the molecular level, GBMs can be divided into four subtypes based on the following gene signatures: classical, mesenchymal, neural and proneural [38]. Amplification of the epidermal growth factor receptor $(E G F R)$ gene is a frequent occurrence in primary GBMs as well as mutations of phosphatase and tensin homolog (PTEN) tumor suppressor gene [39,40]. Interestingly, selected biomarker status is progressively being considered in the clinical assessment and management of certain subtypes of brain tumors such as the evaluation of O6-methylguanine-DNA methyltransferase (MGMT) promoter methylation status in elderly patients diagnosed with a GBM [41].

MiRNAs are appealing therapeutic targets and potential biomarkers of GBMs [42]. Deregulation of these molecules, capable of impacting several processes including cell proliferation, cell cycle regulation and angiogenesis, underlie GBM pathogenesis [43]. Not surprisingly, numerous miRNAs are differentially expressed in primary GBM tumors with targets that notably include transcript coding for proteins with oncogenic or tumor suppressive functions. Early work that assessed miRNA expression via microarray in tissue samples obtained from nine primary GBM patients and ten GBM cell lines notably revealed elevated miR-221 levels in this tumor [44]. It was subsequently demonstrated that the tumor suppressor p27(Kip1), which displays reduced protein levels in GBMs, was a direct miR-221 target [45]. Two additional tumor suppressors, CDKN1A (p21) and CDKN2A (p16), were shown to be direct targets of miR-10b, a miRNA significantly upregulated in malignant gliomas [46]. MiR-21 and miR-26a are also overexpressed in primary GBM tumors and can alter PTEN expression [47,48]. MiR-21 has been associated with GBM cell proliferation and response to cisplatin by targeting FOXO1 [49]. MiR-21 can also impact GBM cell proliferation by regulating Fas ligand (FASLG) protein expression [50]. Interestingly, miR-21 downregulation significantly reduces the oncogenic potential of GBM cell lines independently of PTEN status and affects Akt activity as well as EGFR levels [48]. Expression of the latter is also regulated, directly or indirectly, in GBMs by miRNAs such as miR-7, miR-34a, miR-146b-5p and miR-219-5p [51-54]. The strong invasiveness observed in GBMs is also mediated by differential expression of miRNAs including miR-218, a miRNA that directly targets LEF1 and affects MMP-9 protein levels [55], as well as miR-491-5p and miR-491-3p, which notably target CDK6 and other molecular players linked with GBM cell invasion [56].

While examples abound of modulated miRNAs in primary GBM tumors, miRNAs are also released by GBMs and can be subsequently isolated and quantified in various body fluid samples, thus positioning these molecules as circulating biomarkers of malignancy. A study revealed significant miR-128 
upregulation and miR-342-3p downregulation in blood samples of GBM patients when compared with healthy individuals [57]. Subsequent work confirmed altered miR-128 and miR-342-3p levels in plasma samples of GBM patients and showed that these miRNAs positively correlated with histopathological grades of glioma [58]. It is important to mention that miR-128 levels, as opposed to circulating samples, are reduced in primary GBM specimens which positions this miRNA as an interesting therapeutic target for this malignancy $[59,60]$. Monitoring miRNAs in pre-operative plasma samples also revealed increased miR-21 levels in GBMs [61]. MiR-21 was also identified as significantly upregulated in extra-cellular vesicles (EVs) isolated from cerebrospinal fluid (CSF) of GBM patients when compared with EVs from healthy subjects further supporting the diagnostic relevance of miR-21 [62]. A similar study investigated the miRNA content of serum microvesicles collected from 25 GBM patients and notably highlighted a correlation between miR-320 and miR-574-3p levels and GBM diagnosis [63]. Overall, these studies provide a glimpse of the potential associated with miRNAs as non-invasive biomarkers for GBM diagnosis.

\section{Breast Cancer and MiRNAs}

Breast cancer, unlike GBM, is at the opposite end of the cancer incidence being the most frequent carcinoma observed in women in the United States. It is also the cancer that ranks second on the list of estimated deaths per cancer types for the same gender [64]. As for other types of cancer, early breast cancer detection is of crucial importance to improve the chance of patient survival. Substantial profiling of primary breast tumors has highlighted a variety of subtypes, such as luminal A, luminal B, HER2-enriched and basal-like, with different molecular background and clinical outcomes [65]. The latter subtype also includes triple-negative breast cancer, which lacks immunohistochemical detection of estrogen receptor (ER), progesterone receptor (PR) and human epithelial growth factor receptor-2 (HER-2) [66]. Mutations of the BRCA1 gene, besides conferring a significant lifetime risk of breast cancer diagnosis [67], are also frequently observed in the triple-negative phenotype [68].

Pioneering work performed in tumor samples collected from a cohort of 344 patients diagnosed with primary breast cancer revealed strong miR-21 expression [69]. MiR-21 was correlated with limited disease-free survival in early stage patients. Subsequent work further positioned miR-21 as an important miRNA underlying breast cancer as it displayed strong expression in triple-negative primary breast cancers as well as in breast cancer patients with short disease-free survival [70,71]. Interestingly, and as previously observed in GBMs, miR-21 can target the tumor suppressor protein programmed cell death 4 (PDCD4) in human breast cancer cells [72]. This miRNA can also target, as in GBMs, PTEN in breast cancer and impact the response to chemotherapeutic agents [73]. An overview of the principal miR-21 validated targets in GBMs and breast cancer is presented in Figure 1.

The former study also demonstrated elevated miR-221 and miR-222 expression in the triple-negative specimens. MiR-221/222 is upregulated in HER2-positive primary human breast cancer tissues and has been linked with tamoxifen resistance [74]. MiR-221/222 deregulation leads to modulation of p53 upregulated modulator of apoptosis (PUMA), a pro-apoptotic protein, in human gliomas and breast cancer cells [75,76]. Interestingly, miR-221 can regulate the expression of the tumor suppressor proteins p27 and PTEN in GBMs and breast cancer models [45,77,78]. An overview of the principal miR-221/222 validated targets in GBMs and breast cancer is shown in Figure 2. 
MiR-155 is also one of the first miRNAs to be reported as significantly deregulated in primary breast tumors [79]. Several subsequent studies confirmed miR-155 overexpression in breast cancer tissues [80-82] and recent work presented the tumor protein p53-induced nuclear protein 1 (TP53INP1) as a miR-155 target in MCF-7 cells [83]. MiR-10b is another example of a miRNA with oncogenic properties that is differentially expressed in primary breast cancer. MiR-10b levels in primary breast carcinomas correlate with several clinical parameters including tumor size, pathological grading, clinical staging and lymph node metastasis $[84,85]$. While these oncogenic miRNAs are only the tip of the iceberg when it comes to deregulated miRNAs in breast cancer, it is important to mention that several deregulated miRNAs with tumor suppressive functions have also been identified. Examples include miR-125b, a miRNA that directly targets the ETS1 proto-oncogene in breast cancer [86], which exhibits differential expression between primary and metastatic breast tumors [87] and was most recently reported to impact breast cancer chemoresistance in blood serum samples of breast cancer patients [88]. Downregulation of miR-205, a direct regulator of HER3 receptor expression in breast cancer [89], was observed in primary tumor tissues versus adjacent benign breast tissue [90] and subsequent work in FFPE tissues of patients with early breast cancer further demonstrated that differential expression of this miRNA could impact overall survival [91]. MiR-206 levels were measured in cancer tissues of 128 breast cancer patients via qRT-PCR and revealed reduced expression when compared with normal adjacent tissues [92]. The tumor suppressive properties of miR-206 are likely explained via modulation of its validated target Cyclin D1 [93]. Interestingly, Cyclin D1 is a well-characterized occurrence in primary breast cancer [94] and this further highlights the potential importance of the miR-206-Cyclin D1 axis in this malignancy.

As for GBMs, miRNAs have also been identified in circulating samples of breast cancer patients and have been investigated further for their diagnostic potential [95]. Early work revealed elevated miR-195 levels in blood samples collected from pre-operative breast cancer patients when compared with samples processed from matched controls [96]. The same study also revealed circulating miR-155 overexpression in multiple types of cancer. MiR-155 serum levels were subsequently reported to identify healthy subjects from breast cancer patients further strengthening its diagnostic potential [97,98]. As in primary breast cancer tissues, differential expression of miR-21 in circulating samples has been demonstrated in numerous studies. MiR-21 levels measured by qRT-PCR in serum samples collected from 102 breast cancer patients and 20 healthy female donors highlighted the capacity of this miRNA to discriminate between the two groups [99]. Subsequent work in different cohorts of breast cancer patients further reported miR-21 differential expression between circulating samples collected from patients and samples obtained from healthy individuals $[100,101]$. Novel studies have revealed signatures of multiple miRNAs associated with breast cancer $[102,103]$ and validation of such footprints in other cohorts of breast cancer patients is foreseen to better decipher their clinical relevance.

\section{MiRNAs as Biomarkers: Beyond Diagnostic}

Several miRNAs with diagnostic potential in GBMs and in breast cancer have been presented up to this point and a list of commonly deregulated miRNAs in these two types of cancer is presented in Table 1. 
In addition and as alluded in this article, the clinical usefulness of miRNAs reach beyond their capabilities of diagnosing malignancy. Indeed, miRNAs have also been investigated as prognostic markers. Specific examples in brain tumors include miR-328 which is strongly expressed in glioma cells in vivo and is associated with poor overall patient survival [104] as well as elevated miR-210 levels in serum samples of GBM patients which correlate with poor survival [105]. In breast cancer, miRNA expression by qRT-PCR was performed in blood samples collected from patients and healthy individuals and revealed that miR-200c and miR-141 levels correlated with overall survival [106]. A signature comprising of miR-18b, miR-103, miR-107 and miR-652 efficiently predicted overall survival in serum samples obtained from a cohort of 60 triple-negative breast cancer patients [107]. Examples of miRNAs as potential biomarkers of therapeutic response also exist. In GBMs, elevated MGMT levels confer resistance to the alkylating agent temozolomide (TMZ) [108]. MiR-181d was shown to act as a suitable predictor of TMZ response in GBM cases and to directly regulate MGMT expression [109]. Other examples of miRNAs capable of modulating MGMT expression include miR-221, miR-222, miR-603, miR-648 and miR-767-3p, further supporting the underlying importance of these non-coding RNAs in TMZ response in GBMs [110-112]. MiRNAs such as let-7i, miR-93, miR-130a, miR151-3p, miR-423-5p, miR-938, miR-1238, and miR-1280 have also been correlated with TMZ response in GBMs independently of MGMT status [113,114]. In breast cancer, elevated miR-125b levels were detected in blood serum samples collected from 56 patients and were associated with poor chemotherapeutic response [86]. A study in plasma samples of breast cancer patients also linked circulating miR-210 levels with trastuzumab resistance [115]. While this review has focused on the diagnostic potential of miRNAs, there is clear evidence that these molecules also possess additional clinical properties.

\section{Conclusions}

In addition to miRNAs, it is important to mention that other non-coding RNAs such as long non-coding RNAs (lncRNAs) are appealing molecules to investigate for their diagnostic potential in different types of cancer. While the information available regarding lncRNAs as potential cancer biomarkers in human in vivo models is not as vast as for the miRNAs, interesting work is starting to emerge in this research area. Two studies notably reported elevated HOX antisense intergenic RNA (HOTAIR) lncRNA levels in blood samples collected from cervical and colorectal cancer patients and correlated this observation with poor prognosis [116,117]. In gliomas, the identification of subtypes based on lncRNA expression provided pioneering work for the clinical relevance of lncRNAs in brain tumors [118]. MEG3, an lncRNA with tumor-suppressive functions, displayed significant downregulation in glioma tissue samples when compared with adjacent normal tissues and its overexpression in two GBM cell lines promoted apoptosis [119]. Early work in breast cancer FFPE tissues notably showed that strong HOTAIR expression was linked with ER and PR expression [120] and a recent study observed elevated lncRNA RP11-445H22.4 levels in serum samples collected from a cohort of 136 breast cancer patients [121].

In conclusion, whether to monitor treatment response in GBMs or for early breast cancer detection, several examples exist that illustrate non-coding RNAs with diagnostic, prognostic and therapeutic response assessment potential. Deciphering the circulating miRNA footprint associated with these malignancies is undoubtedly of great clinical interest and tremendous progress has been made in this 
research area in recent years. Nevertheless, challenges remain before non-coding RNAs are leveraged as bona fide biomarkers in the two types of cancer explored in this review and further investigation is needed in this research field to unveil clinically relevant miRNA-based signatures.

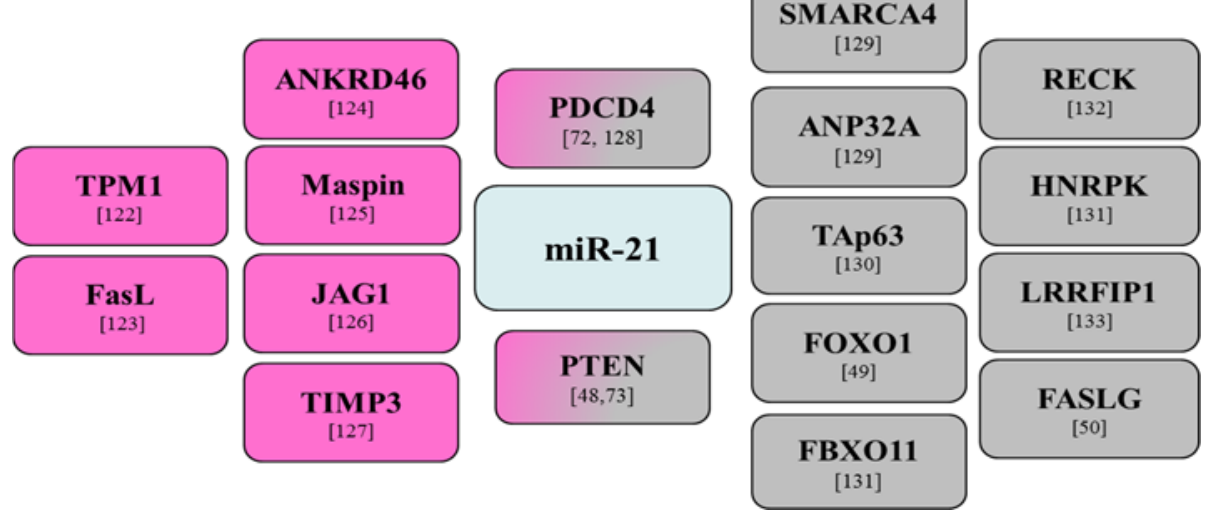

Figure 1. MiR-21 validated targets in glioblastoma multiforme and breast cancer studies. Targets in breast cancer are shown in pink and targets in glioblastoma multiforme are shown in gray.

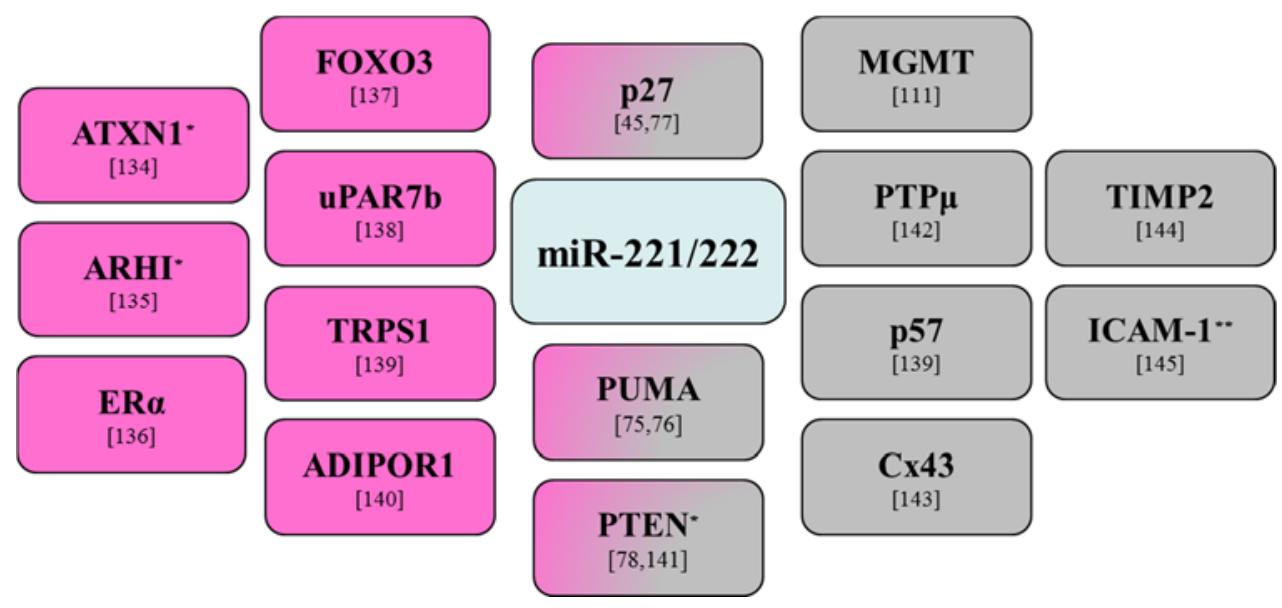

Figure 2. MiR-221/222 validated targets in glioblastoma multiforme and breast cancer studies. Targets in breast cancer are shown in pink and targets in glioblastoma multiforme are shown in gray. * Targets regulated by miR-221 alone. ** Target regulated by miR-222 alone. 
Table 1. Commonly deregulated microRNAs (miRNAs) in primary and circulating glioblastoma multiforme (GBM) and breast cancer (BC) samples. BC: Differential expression of miRNA only reported in breast cancer.

\begin{tabular}{cccc}
\hline miRNA & Differential expression & Sample type & References \\
\hline miR-7-5p & Downregulated & Primary tumors & {$[146,147]$} \\
miR-10b & Upregulated & $\begin{array}{c}\text { Primary tumors } \\
\text { Serum }(B C)\end{array}$ & {$[148-151]$} \\
miR-17/92 & Upregulated & $\begin{array}{c}\text { Primary tumors } \\
\text { Primary tumors }\end{array}$ & {$[152,153]$} \\
miR-21 & Upregulated & Plasma & {$[61,69,154,155]$} \\
& & Primary tumors & {$[79,150,156]$} \\
miR-155 & Upregulated & Serum (BC) & {$[157,158]$} \\
miR-182 & Upregulated & Primary tumors & {$[44,70]$} \\
miR-221 & Upregulated & Primary tumors & {$[44,74]$} \\
miR-222 & Upregulated & Primary tumors & \\
\hline
\end{tabular}

\section{Acknowledgments}

Pier Jr Morin is supported by the Beatrice Hunter Cancer Research Institute (BHCRI), the New Brunswick Health Research Foundation (NBHRF), the New Brunswick Innovation Foundation (NBIF) and the Université de Moncton. Véronique C. LeBlanc would also like to thank the BHCRI and the NBHRF for funding.

\section{Author Contributions}

Véronique C. LeBlanc wrote parts of the manuscript and created the table and figures. Pier Jr Morin wrote parts of the manuscript and edited the document.

\section{Conflicts of Interest}

The authors declare no conflict of interest.

\section{References}

1. Leivonen, S.K.; Sahlberg, K.K.; Mäkelä, R.; Due, E.U.; Kallioniemi, O.; Børresen-Dale, A.L.; Perälä, M. High-throughput screens identify microRNAs essential for HER2 positive breast cancer cell growth. Mol. Oncol. 2014, 8, 93-104.

2. Rupaimoole, R.; Wu, S.Y.; Pradeep, S.; Ivan, C.; Pecot, C.V.; Gharpure, K.M.; Nagaraja, A.S.; Armaiz-Pena, G.N.; McGuire, M.; Zand, B.; et al. Hypoxia-mediated downregulation of miRNA biogenesis promotes tumour progression. Nat. Commun. 2014, 5, doi:10.1038/ncomms6202.

3. Valeri, N.; Braconi, C.; Gasparini, P.; Murgia, C.; Lampis, A.; Paulus-Hock, V.; Hart, J.R.; Ueno, L.; Grivennikov, S.I.; Lovat, F.; et al. MicroRNA-135b promotes cancer progression by acting as a downstream effector of oncogenic pathways in colon cancer. Cancer Cell 2014, 25, 469-483. 
4. Chen, X.; Ba, Y.; Ma, L.; Cai, X.; Yin, Y.; Wang, K.; Guo, J.; Zhang, Y.; Chen, J.; Guo, X.; et al. Characterization of microRNAs in serum: A novel class of biomarkers for diagnosis of cancer and other diseases. Cell Res. 2008, 18, 997-1006.

5. Kodahl, A.R.; Lyng, M.B.; Binder, H.; Cold, S.; Gravgaard, K.; Knoop, A.S.; Ditzel, H.J. Novel circulating microRNA signature as a potential non-invasive multi-marker test in ER-positive early-stage breast cancer: A case control study. Mol. Oncol. 2014, 8, 874-883.

6. Hansen, T.F.; Carlsen, A.L.; Heegaard, N.H.; Sørensen, F.B.; Jakobsen, A. Changes in circulating microRNA-126 during treatment with chemotherapy and bevacizumab predicts treatment response in patients with metastatic colorectal cancer. Br. J. Cancer 2015, 112, 624-629.

7. Lee, L.; Kim, M.; Han, J.; Yeom, K.H.; Lee, S.; Baek, S.H.; Kim, V.N. MicroRNA genes are transcribed by RNA polymerase II. EMBO J. 2004, 23, 4051-4060.

8. Borchert, G.M.; Lanier, W.; Davidson, B.L. RNA polymerase III transcribes human microRNAs. Nat. Struct. Mol. Biol. 2006, 13, 1097-1101.

9. Lee, Y.; Jeon, K.; Lee J.T.; Kim, S.; Kim, V.N. MicroRNA maturation: Stepwise processing and subcellular localization. EMBO J. 2002, 21, 4663-4670.

10. Yi, R.; Qin, Y.; Macara, I.G.; Cullen, B.R. Exportin-5 mediates the nuclear export of pre-microRNAs and short hairpin RNAs. Genes Dev. 2003, 17, 3011-3016.

11. Cai, X.; Hagedorn, C.H.; Cullen, B.R. Human microRNAs are processed from capped, polyadenylated transcripts that can also function as mRNAs. RNA 2004, 10, 1957-1966.

12. Landthaler, M.; Yalcin, A.; Tuschl, T. The human DiGeorge syndrome critical region gene 8 and its D. melanogaster homolog are required for miRNA biogenesis. Curr. Biol. 2004, 14, 2162-2167.

13. Bernstein, E.; Caudy, A.A.; Hammond, S.M.; Hannon, G.J. Role for a bidentate ribonuclease in the initiation step of RNA interference. Nature 2001, 409, 363-366.

14. Meister, G.; Landthaler, M.; Patkaniowska, A.; Dorsett, Y.; Teng, G.; Tuschl, T. Human Argonaute2 mediates RNA cleavage targeted by miRNAs and siRNAs. Mol. Cell 2004, 15, 185-197.

15. Lewis, B.P.; Shih, I.H.; Jones-Rhoades, M.W.; Bartel, D.P.; Burge, C.B. Prediction of mammalian microRNA targets. Cell 2003, 115, 787-798.

16. Lee, I.; Ajay, S.S.; Yook, J.I.; Kim, H.S.; Hong, S.H.; Kim, N.H.; Dhanasekaran, S.M.; Chinnaiyan, A.M.; Athey, B.D. New class of microRNA targets containing simultaneous 5-UTR and 3-UTR interaction site. Genome Res. 2009, 19, 1175-1183.

17. Brümmer, A.; Hausser, J. MicroRNA binding sites in the coding region of mRNAs: Extending the repertoire of post-transcriptional gene regulation. Bioessays 2014, 36, 617-626.

18. Valadi, H.; Ekström, K.; Bossios, A.; Sjöstrand, M.; Lee, J.J.; Lötvall, J.O. Exosome-mediated transfer of mRNAs and microRNAs is a novel mechanism of genetic exchange between cells. Nat. Cell Biol. 2007, 9, 654-659.

19. Ohshima, K.; Inoue, K.; Fujiwara, A.; Hatakeyama, K.; Kanto, K.; Watanabe, Y.; Muramatsu, K.; Fukuda, Y.; Ogura, S.; Yamaguchi, K.; et al. Let-7 microRNA family is selectively secreted into the extracellular environment via exosomes in a metastatic gastric cancer cell line. PLoS ONE 2010, 5, e13247. 
20. Wei, Y.; Lai, X.; Yu, S.; Chen, S.; Ma, Y.; Zhang, Y.; Li, H.; Zhu, X.; Yao, L.; Zhang, J. Exosomal miR-221/222 enhances tamoxifen resistance in recipient ER-positive breast cancer cells. Breast Cancer Res. Treat. 2014, 147, 423-431.

21. Friel, A.M.; Corcoran, C.; Crown, J.; O’Driscoll, L. Relevance of circulating tumor cells, extracellular nucleic acids, and exosomes in breast cancer. Breast Cancer Res. Treat. 2010, 123, 613-625.

22. Santiago-Dieppa, D.R.; Steinberg, J.; Gonda, D.; Cheung, V.J.; Carter, B.S.; Chen, C.C. Extracellular vesicles as a platform for "liquid biopsy" in glioblastoma patients. Expert Rev. Mol. Diagn. 2014, $14,819-825$.

23. Lawrie, C.H.; Gal, S.; Dunlop, H.M.; Pushkaran, B.; Liggins, A.P.; Pulford, K.; Banham, A.H.; Pezzella, F.; Boultwood, J.; Wainscoat, J.S; et al. Detection of elevated levels of tumour-associated microRNAs in serum of patients with diffuse large B-cell lymphoma. Br. J. Haematol. 2008, 141, 672-675.

24. Park, N.J.; Zhou, H.; Elashoff, D.; Hemson, B.S.; Kastratovic, D.A.; Abemayor, E.; Wong, D.T. Salivary microRNA: Discovery, characterization, and clinical utility for oral cancer detection. Clin. Cancer Res. 2009, 15, 5473-5477.

25. Hanke, M.; Hoefig, K.; Merz, H.; Feller, A.C.; Kausch, I.; Jocham, D.; Warnecke, J.M.; Sczakiel, G. A robust methodology to study urine microRNA as tumor marker: microRNA-126 and microRNA182 are related to urinary bladder cancer. Urol. Oncol. 2010, 28, 655-661.

26. Mitchell, P.S.; Parkin, R.K.; Kroh, E.M.; Fritz, B.R.; Wyman, S.K.; Pogosova-Agadjanyan, E.L.; Peterson, A.; Noteboom, J.; O’Briant, K.C.; Allen, A.; et al. Circulating microRNAs as stable blood-based markers for cancer detection. Proc. Natl. Acad. Sci. USA 2008, 105, 10513-10518.

27. Mall, C.; Rocke, D.M.; Durbin-Johnson, B.; Weiss, R.H. Stability of miRNA in human urine supports its biomarker potential. Biomark. Med. 2013, 7, 623-631.

28. Kakimoto, Y.; Kamiguchi, H.; Ochiai, E.; Satoh, F.; Osawa, M. MicroRNA Stability in Postmortem FFPE Tissues: Quantitative Analysis Using Autoptic Samples from Acute Myocardial Infarction Patients. PLOS ONE 2015, 10, e0129338.

29. Lodes, M.J.; Caraballo, M.; Suciu, D.; Munro, S.; Kumar, A.; Anderson, B. Detection of cancer with serum miRNAs on an oligonucleotide microarray. PLOS ONE 2009, 4, 1-12.

30. Kroh, E.M.; Parkin, R.K.; Mitchell, P.S.; Tewari, M. Analysis of circulating microRNA biomarkers in plasma and serum using quantitative reverse transcription-PCR (qRT-PCR). Methods 2010, 50, 298-301.

31. Dedeoğlu, B.G. High-throughput approaches for microRNA expression analysis. Methods Mol. Biol. 2014, 1107, 91-103.

32. Schetter, A.J.; Leung, S.Y.; Sohn, J.J.; Zanetti, K.A.; Bowman, E.D.; Yanaihara, N.; Yuen, S.T.; Chan, T.L.; Kwong, D.L.; Au, G.K.; et al. MicroRNA expression profiles associated with prognosis and therapeutic outcome in colonadenocarcinoma. JAMA 2008, 299, 425-436.

33. Zhou, W.; Fong, M.Y.; Min, Y.; Somlo, G.; Liu, L.; Palomares, M.R.; Yu, Y.; Chow, A.; O'Connor, S.T.; Chin, A.R.; et al. Cancer-secreted miR-105 destroys vascular endothelial barriers to promote metastasis. Cancer Cell 2014, 25, 501-515.

34. Davis, F.G.; McCarthy, B.J. Current epidemiological trends and surveillance issues in brain tumors. Expert Rev. Anticancer Ther. 2001, 1, 395-401. 
35. Louis, D.N.; Ohgaki, H.; Wiestler, O.D.; Cavenee, W.K.; Burger, P.C.; Jouvet, A.; Scheithauer, B.W.; Kleihues, P. The 2007 WHO classification of tumours of the central nervous system. Acta Neuropathol. 2007, 114, 97-109.

36. Huse, J.T.; Holland, E.C. Targeting brain cancer: Advances in the molecular pathology of malignant glioma and medulloblastoma. Nat. Rev. Cancer 2010, 10, 319-331.

37. Stupp, R.; Mason, W.P.; van den Bent, M.J.; Weller, M.; Fisher, B.; Taphoorn, M.J.B.; Belanger, K.; Brandes, A.A.; Marosi, C.; Bogdahn, U.; et al. Radiotherapy plus concomitant and adjuvant temozolomide for glioblastoma. N. Engl. J. Med. 2005, 352, 987-996.

38. Verhaak, R.G.; Hoadley, K.A.; Purdom, E.; Wang, V.; Qi, Y.; Wilkerson, M.D.; Miller, C.R.; Ding, L.; Golub, T.; Mesirov, J.P.; et al. Cancer Genome Atlas Research Network. Integrated genomic analysis identifies clinically relevant subtypes of glioblastoma characterized by abnormalities in PDGFRA, IDH1, EGFR, and NF1. Cancer Cell 2010, 17, 98-110.

39. Wong, A.J.; Bigner, S.H.; Bigner, D.D.; Kinzler, K.W.; Hamilton, S.R.; Vogelstein, B. Increased expression of the epidermal growth factor receptor gene in malignant gliomas is invariably associated with gene amplification. Proc. Natl. Acad. Sci. USA 1987, 84, 6899-6903.

40. Wang, S.I.; Puc, J.; Li, J.; Bruce, J.N.; Cairns, P.; Sidransky, D.; Parsons, R. Somatic mutations of PTEN in glioblastoma multiforme. Cancer Res. 1997, 57, 4183-4186.

41. Weller, M.; Pfister, S.M.; Wick, W.; Hegi, M.E.; Reifenberger, G.; Stupp, R. Molecular neuro-oncology in clinical practice: A new horizon. Lancet Oncol. 2013, 14, e370-e379.

42. Hummel, R.; Maurer, J.; Haier, J. MicroRNAs in brain tumors: A new diagnostic and therapeutic perspective. Mol. Neurobiol. 2011, 44, 223-234.

43. Novakova, J.; Slaby, O.; Vyzula, R.; Michalek, J. MicroRNA involvement in glioblastoma pathogenesis. Biochem. Biophys. Res. Commun. 2009, 386, 1-5.

44. Ciafrè, S.A.; Galardi, S.; Mangiola, A.; Ferracin, M.; Liu, C.G.; Sabatino, G.; Negrini, M.; Maira, G.; Croce, C.M.; Farace, M.G. Extensive modulation of a set of microRNAs in primary glioblastoma. Biochem. Biophys. Res. Commun. 2005, 334, 1351-1358.

45. Gillies, J.K.; Lorimer, I.A. Regulation of p27Kip1 by miRNA 221/222 in glioblastoma. Cell Cycle 2007, 6, 2005-2009.

46. Gabriely, G.; Yi, M.; Narayan, R.S.; Niers, J.M.; Wurdinger, T.; Imitola, J.; Ligon, K.L.; Kesari, S.; Esau, C.; Stephens, R.M.; et al. Human glioma growth is controlled by microRNA-10b. Cancer Res. 2011, 71, 3563-3572.

47. Kim, H.; Huang, W.; Jiang, X.; Pennicooke, B.; Park, P.J.; Johnson, M.D. Integrative genome analysis reveals an oncomir/oncogene cluster regulating glioblastoma survivorship. Proc. Natl. Acad. Sci. USA 2010, 107, 2183-2188.

48. Zhou, X.; Ren, Y.; Moore, L.; Mei, M.; You, Y.; Xu, P.; Wang, B.; Wang, G.; Jia, Z.; Pu, P.; et al. Downregulation of miR-21 inhibits EGFR pathway and suppresses the growth of human glioblastoma cells independent of PTEN status. Lab. Investig. 2010, 90, 144-155.

49. Lei, B.X.; Liu, Z.H.; Li, Z.J.; Li, C.; Deng, Y.F. miR-21 induces cell proliferation and suppresses the chemosensitivity in glioblastoma cells via downregulation of FOXO1. Int. J. Clin. Exp. Med. 2014, 7, 2060-2066. 
50. Shang, C.; Guo, Y.; Hong, Y.; Liu, Y.H.; Xue, Y.X. MiR-21 up-regulation mediates glioblastoma cancer stem cells apoptosis and proliferation by targeting FASLG. Mol. Biol. Rep. 2015, 42, 721-727.

51. Kefas, B.; Godlewski, J.; Comeau, L.; Li, Y.; Abounader, R.; Hawkinson, M.; Lee, J.; Fine, H.; Chiocca, E.A.; Lawler, S.; et al. MicroRNA-7 inhibits the epidermal growth factor receptor and the Akt pathway and is down-regulated in glioblastoma. Cancer Res. 2008, 68, 3566-3572.

52. Katakowski, M.; Zheng, X.; Jiang, F.; Rogers, T.; Szalad, A.; Chopp, M. MiR-146b-5p suppresses EGFR expression and reduces in vitro migration and invasion of glioma. Cancer Investig. 2010, 28, 1024-1030.

53. Rao, S.A.; Arimappamagan, A.; Pandey, P.; Santosh, V.; Hegde, A.S.; Chandramouli, B.A.; Somasundaram, K. miR-219-5p inhibits receptor tyrosine kinase pathway by targeting EGFR in glioblastoma. PLoS ONE 2013, 8, e63164.

54. Yin, D.; Ogawa, S.; Kawamata, N.; Leiter, A.; Ham, M.; Li, D.; Doan, N.B.; Said, J.W.; Black, K.L.; Phillip Koeffler, H. miR-34a functions as a tumor suppressor modulating EGFR in glioblastoma multiforme. Oncogene 2013, 32, 1155-1163.

55. Liu, Y.; Yan, W.; Zhang, W.; Chen, L.; You, G.; Bao, Z.; Wang, Y.; Wang, H.; Kang, C.; Jiang, T. MiR-218 reverses high invasiveness of glioblastoma cells by targeting the oncogenic transcription factor LEF1. Oncol. Rep. 2012, 28, 1013-1021.

56. Li, X.; Liu, Y.; Granberg, K.J.; Wang, Q.; Moore, L.M.; Ji, P.; Gumin, J.; Sulman, E.P.; Calin, G.A.; Haapasalo, H.; et al. Two mature products of MIR-491 coordinate to suppress key cancer hallmarks in glioblastoma. Oncogene 2015, 34, 1619-1628.

57. Roth, P.; Wischhusen, J.; Happold, C.; Chandran, P.A.; Hofer, S.; Eisele, G.; Weller, M.; Keller, A. A specific miRNA signature in the peripheral blood of glioblastoma patients. J. Neurochem. 2011, $118,449-457$.

58. Wang, Q.; Li, P.; Li, A.; Jiang, W.; Wang, H.; Wang, J.; Xie, K. Plasma specific miRNAs as predictive biomarkers for diagnosis and prognosis of glioma. J. Exp. Clin. Cancer Res. 2012, 31, doi:10.1186/1756-9966-31-97.

59. Godlewski, J.; Nowicki, M.O.; Bronisz, A.; Williams, S.; Otsuki, A.; Nuovo, G.; Raychaudhury, A.; Newton, H.B.; Chiocca, E.A.; Lawler, S. Targeting of the Bmi-1 oncogene/stem cell renewal factor by microRNA-128 inhibits glioma proliferation and self-renewal. Cancer Res. 2008, 68, 9125-9130.

60. Papagiannakopoulos, T.; Friedmann-Morvinski, D.; Neveu, P.; Dugas, J.C.; Gill, R.M.; Huillard, E.; Liu, C.; Zong, H.; Rowitch, D.H.; Barres, B.A.; et al. Pro-neural miR-128 is a glioma tumor suppressor that targets mitogenic kinases. Oncogene 2012, 31, 1884-1895.

61. Ilhan-Mutlu, A.; Wagner, L.; Wöhrer, A.; Furtner, J.; Widhalm, G.; Marosi, C.; Preusser, M. Plasma MicroRNA-21 concentration may be a useful biomarker in glioblastoma patients. Cancer Investig. 2012, 30, 615-621.

62. Akers, J.C.; Ramakrishnan, V.; Kim, R.; Skog, J.; Nakano, I.; Pingle, S.; Kalinina, J.; Hua, W.; Kesari, S.; Mao, Y.; et al. MiR-21 in the extracellular vesicles (EVs) of cerebrospinal fluid (CSF): A platform for glioblastoma biomarker development. PLOS ONE 2013, 8, e78115. 
63. Manterola, L.; Guruceaga, E.; Gállego Pérez-Larraya, J.; González-Huarriz, M.; Jauregui, P.; Tejada, S.; Diez-Valle, R.; Segura, V.; Samprón, N.; Barrena, C.; et al. A small noncoding RNA signature found in exosomes of GBM patient serum as a diagnostic tool. Neuro-Oncology 2014, $16,520-527$.

64. Jemal, A.; Siegel, R.; Xu, J.; Ward, E. Cancer statistics, 2010. CA Cancer J. Clin. 2010, 60, 277-300.

65. Curtis, C.; Shah, S.P.; Chin, S.F.; Turashvili, G.; Rueda, O.M.; Dunning, M.J.; Speed, D.; Lynch, A.G.; Samarajiwa, S.; Yuan, Y.; et al. The genomic and transcriptomic architecture of 2000 breast tumours reveals novel subgroups. Nature 2012, 486, 346-352.

66. Livasy, C.A.; Karaca, G.; Nanda, R.; Tretiakova, M.S.; Olopade, O.I.; Moore, D.T.; Perou, C.M. Phenotypic evaluation of the basal-like subtype of invasive breast carcinoma. Modern Pathol. 2006, 19, 264-271.

67. Narod, S.A.; Foulkes, W.D. BRCA1 and BRCA2: 1994 and beyond. Nat. Rev. Cancer 2004, 4, 665-676.

68. Arnes, J.B.; Brunet, J.S.; Stefansson, I.; Bégin, L.R.; Wong, N.; Chappuis, P.O.; Akslen, L.A.; Foulkes, W.D. Placental cadherin and the basal epithelial phenotype of BRCA1-related breast cancer. Clin. Cancer Res. 2005, 11, 4003-4011.

69. Qian, B.; Katsaros, D.; Lu, L.; Preti, M.; Durando, A.; Arisio, R.; Mu, L.; Yu, H. High miR-21 expression in breast cancer associated with poor disease-free survival in early stage disease and high TGF-beta1. Breast Cancer Res. Treat. 2009, 117, 131-140.

70. Radojicic, J.; Zaravinos, A.; Vrekoussis, T.; Kafousi, M.; Spandidos, D.A.; Stathopoulos, E.N. MicroRNA expression analysis in triple-negative (ER, PR and Her2/neu) breast cancer. Cell Cycle 2011, 10, 507-517.

71. Ozgün, A.; Karagoz, B.; Bilgi, O.; Tuncel, T.; Baloglu, H.; Kandemir, E.G. MicroRNA-21 as an indicator of aggressive phenotype in breast cancer. Onkologie 2013, 36, 115-118.

72. Sun, X.; Luo, S.; He, Y.; Shao, Y.; Liu, C.; Chen, Q.; Cui, S.; Liu, H. Screening of the miRNAs related to breast cancer and identification of its target genes. Eur. J. Gynaecol. Oncol. 2014, 35, 696-700.

73. Wang, Z.X.; Lu, B.B.; Wang, H.; Cheng, Z.X.; Yin, Y.M. MicroRNA-21 modulates chemosensitivity of breast cancer cells to doxorubicin by targeting PTEN. Arch. Med. Res. 2011, 42, 281-290.

74. Miller, T.E.; Ghoshal, K.; Ramaswamy, B.; Roy, S.; Datta, J.; Shapiro, C.L.; Jacob, S.; Majumder, S. MicroRNA-221/222 confers tamoxifen resistance in breast cancer by targeting p27Kip1. J. Biol. Chem. 2008, 283, 29897-29903.

75. Zhang, C.Z.; Zhang, J.X.; Zhang, A.L.; Shi, Z.D.; Han, L.; Jia, Z.F.; Yang, W.D.; Wang, G.X.; Jiang, T.; You, Y.P.; et al. MiR-221 and miR-222 target PUMA to induce cell survival in glioblastoma. Mol. Cancer 2010, 9, 229.

76. Zhang, C.; Zhang, J.; Zhang, A.; Wang, Y.; Han, L.; You, Y.; Pu, P.; Kang, C. PUMA is a novel target of miR-221/222 in human epithelial cancers. Int. J. Oncol. 2010, 37, 1621-1626.

77. Medina, R.; Zaidi, S.K.; Liu, C.G.; Stein, J.L.; van Wijnen, A.J.; Croce, C.M.; Stein, G.S. MicroRNAs 221 and 222 bypass quiescence and compromise cell survival. Cancer Res. 2008, 68, 2773-2780. 
78. Ye, X.; Bai, W.; Zhu, H.; Zhang, X.; Chen, Y.; Wang, L.; Yang, A.; Zhao, J.; Jia, L. MiR-221 promotes trastuzumab-resistance and metastasis in HER2-positive breast cancers by targeting PTEN. BMB Rep. 2014, 47, 268-273.

79. Iorio, M.V.; Ferracin, M.; Liu, C.G.; Veronese, A.; Spizzo, R.; Sabbioni, S.; Magri, E.; Pedriali, M.; Fabbri, M.; Campiglio, M.; et al. MicroRNA gene expression deregulation in human breast cancer. Cancer Res. 2005, 65, 7065-7070.

80. Jiang, S.; Zhang, H.W.; Lu, M.H.; He, X.H.; Li, Y.; Gu, H.; Liu, M.F.; Wang, E.D. MicroRNA-155 functions as an OncomiR in breast cancer by targeting the suppressor of cytokine signaling 1 gene. Cancer Res. 2010, 70, 3119-3127.

81. Kong, W.; He, L.; Coppola, M.; Guo, J.; Esposito, N.N.; Coppola, D.; Cheng, J.Q. MicroRNA-155 regulates cell survival, growth, and chemosensitivity by targeting FOXO3a in breast cancer. J. Biol. Chem. 2010, 285, 17869-17879.

82. Ouyang, M.; Li, Y.; Ye, S.; Ma, J.; Lu, L.; Lv, W.; Chang, G.; Li, X.; Li, Q.; Wang, S.; et al. MicroRNA profiling implies new markers of chemoresistance of triple-negative breast cancer. PLOS ONE 2014, 9, e96228.

83. Zhang, C.M.; Zhao, J.; Deng, H.Y. MiR-155 promotes proliferation of human breast cancer MCF-7 cells through targeting tumor protein 53-induced nuclear protein 1. J. Biomed. Sci. 2013, 20, 79.

84. Ma, L.; Teruya-Feldstein, J.; Weinberg, R.A. Tumour invasion and metastasis initiated by microRNA-10b in breast cancer. Nature 2007, 449, 682-688.

85. Liu, Y.; Zhao, J.; Zhang, P.Y.; Zhang, Y.; Sun, S.Y.; Yu, S.Y.; Xi, Q.S. MicroRNA-10b targets E-cadherin and modulates breast cancer metastasis. Med. Sci. Monitor 2012, 18, BR299-BR308.

86. Zhang, Y.; Yan, L.X.; Wu, Q.N.; Du, Z.M.; Chen, J.; Liao, D.Z.; Huang, M.Y.; Hou, J.H.; $\mathrm{Wu}$, Q.L.; Zeng, M.S.; et al. miR-125b is methylated and functions as a tumor suppressor by regulating the ETS1 proto-oncogene in human invasive breast cancer. Cancer Res. 2011, 71, 3552-3562.

87. Baffa, R.; Fassan, M.; Volinia, S.; O’Hara, B.; Liu, C.G.; Palazzo, J.P.; Gardiman, M.; Rugge, M.; Gomella, L.G.; Croce, C.M.; et al. MicroRNA expression profiling of human metastatic cancers identifies cancer gene targets. J. Pathol. 2009, 219, 214-221.

88. Wang, H.; Tan, G.; Dong, L.; Cheng, L.; Li, K.; Wang, Z.; Luo, H. Circulating MiR-125b as a marker predicting chemoresistance in breast cancer. PLOS ONE 2012, 7, e34210.

89. Iorio, M.V.; Casalini, P.; Piovan, C.; Di Leva, G.; Merlo, A.; Triulzi, T.; Ménard, S.; Croce, C.M.; Tagliabue, E. microRNA-205 regulates HER3 in human breast cancer. Cancer Res. 2009, 69, 2195-2200.

90. Elgamal, O.A.; Park, J.K.; Gusev, Y.; Azevedo-Pouly, A.C.; Jiang, J.; Roopra, A.; Schmittgen, T.D. Tumor suppressive function of mir-205 in breast cancer is linked to HMGB3 regulation. PLoS ONE 2013, 8, e76402.

91. Markou, A.; Yousef, G.M.; Stathopoulos, E.; Georgoulias, V.; Lianidou, E. Prognostic significance of metastasis-related microRNAs in early breast cancer patients with a long follow-up. Clin. Chem. 2014, 60, 197-205.

92. Li, Y.; Hong, F.; Yu, Z. Decreased expression of microRNA-206 in breast cancer and its association with disease characteristics and patient survival. J. Int. Med. Res. 2013, 41, 596-602. 
93. Elliman, S.J.; Howley, B.V.; Mehta, D.S.; Fearnhead, H.O.; Kemp, D.M.; Barkley, L.R. Selective repression of the oncogene cyclin D1 by the tumor suppressor miR-206 in cancers. Oncogenesis 2014, 3, e113.

94. Elsheikh, S.; Green, A.R.; Aleskandarany, M.A.; Grainge, M.; Paish, C.E.; Lambros, M.B.; Reis-Filho, J.S.; Ellis, I.O. CCND1 amplification and cyclin D1 expression in breast cancer and their relation with proteomic subgroups and patient outcome. Breast Cancer Res. Treat. 2008, 109, $325-335$.

95. Schwarzenbach, H. Circulating nucleic acids as biomarkers in breast cancer. Breast Cancer Res. 2013, 15, 211.

96. Heneghan, H.M.; Miller, N.; Kelly, R.; Newell, J.; Kerin, M.J. Systemic miRNA-195 differentiates breast cancer from other malignancies and is a potential biomarker for detecting noninvasive and early stage disease. Oncologist 2010, 15, 673-682.

97. Roth, C.; Rack, B.; Müller, V.; Janni, W.; Pantel, K.; Schwarzenbach, H. Circulating microRNAs as blood-based markers for patients with primary and metastatic breast cancer. Breast Cancer Res. 2010, 12, R90.

98. Sun, Y.; Wang, M.; Lin, G.; Sun, S.; Li, X.; Qi, J.; Li, J. Serum microRNA-155 as a potential biomarker to track disease in breast cancer. PLOS ONE 2012, 7, e47003.

99. Asaga, S.; Kuo, C.; Nguyen, T.; Terpenning, M.; Giuliano, A.E.; Hoon, D.S. Direct serum assay for microRNA-21 concentrations in early and advanced breast cancer. Clin. Chem. 2011, 57, 84-91.

100. Chan, M.; Liaw, C.S.; Ji, S.M.; Tan, H.H.; Wong, C.Y.; Thike, A.A.; Tan, P.H.; Ho, G.H.; Lee, A.S. Identification of circulating microRNA signatures for breast cancer detection. Clin. Cancer Res. 2013, 19, 4477-4487.

101. Kumar, S.; Keerthana, R.; Pazhanimuthu, A.; Perumal, P. Overexpression of circulating miRNA-21 and miRNA-146a in plasma samples of breast cancer patients. Indian J. Biochem. Biophys. 2013, 50, 210-214.

102. Matamala, N.; Vargas, M.T.; González-Cámpora, R.; Miñambres, R.; Arias, J.I.; Menéndez, P.; Andrés-León, E.; Gómez-López, G.; Yanowsky, K.; Calvete-Candenas, J.; et al. Tumor MicroRNA Expression Profiling Identifies Circulating MicroRNAs for Early Breast Cancer Detection. Clin. Chem. 2015, 61, 1098-1106.

103. Shin, V.Y.; Siu, J.M.; Cheuk, I.; Ng, E.K.; Kwong, A. Circulating cell-free miRNAs as biomarker for triple-negative breast cancer. Br. J. Cancer 2015, 112, 1751-1759.

104. Delic, S.; Lottmann, N.; Stelzl, A.; Liesenberg, F.; Wolter, M.; Götze, S.; Zapatka, M.; Shiio, Y.; Sabel, M.C.; Felsberg, J.; et al. MiR-328 promotes glioma cell invasion via SFRP1-dependent Wnt-signaling activation. Neuro-Oncology 2014, 16, 179-190.

105. Lai, N.S.; Wu, D.G.; Fang, X.G.; Lin, Y.C.; Chen, S.S.; Li, Z.B.; Xu, S.S. Serum microRNA-210 as potential noninvasive biomarker for the diagnosis and prognosis of glioma. Br. J. Cancer 2015, 112, 1241-1246.

106. Antolín, S.; Calvo, L.; Blanco-Calvo, M.; Santiago, M.P.; Lorenzo-Patiño, M.J.; Haz-Conde, M.; Santamarina, I.; Figueroa, A.; Antón-Aparicio, L.M.; Valladares-Ayerbes, M. Circulating miR-200c and miR-141 and outcomes in patients with breast cancer. BMC Cancer 2015, 15, doi:10.1186/s12885-015-1238-5. 
107. Kleivi Sahlberg, K.; Bottai, G.; Naume, B.; Burwinkel, B.; Calin, G.A.; Børresen-Dale, A.L.; Santarpia, L. A serum microRNA signature predicts tumor relapse and survival in triple-negative breast cancer patients. Clin. Cancer Res. 2015, 21, 1207-1214.

108. Bocangel, D.B.; Finkelstein, S.; Schold, S.C.; Bhakat, K.K.; Mitra, S.; Kokkinakis, D.M. Mulfaceted resistance of gliomas to temozolomide. Clin. Cancer Res. 2002, 8, 2725-2734.

109. Zhang, W.; Zhang, J.; Hoadley, K.; Kushwaha, D.; Ramakrishnan, V.; Li, S.; Kang, C.; You, Y.; Jiang, C.; Song, S.W.; et al. miR-181d: A predictive glioblastoma biomarker that downregulates MGMT expression. Neuro-Oncology 2012, 14, 712-719.

110. Kreth, S.; Limbeck, E.; Hinske, L.C.; Schütz, S.V.; Thon, N.; Hoefig, K.; Egensperger, R.; Kreth, F.W. In human glioblastomas transcript elongation by alternative polyadenylation and miRNA targeting is a potent mechanism of MGMT silencing. Acta Neuropathol. 2013, 125, 671-681.

111. Quintavalle, C.; Mangani, D.; Roscigno, G.; Romano, G.; Diaz-Lagares, A.; Iaboni, M.; Donnarumma, E.; Fiore, D.; de Marinis, P.; Soini, Y.; et al. MiR-221/222 target the DNA methyltransferase MGMT in glioma cells. PLOS ONE 2013, 8, e74466.

112. Kushwaha, D.; Ramakrishnan, V.; Ng, K.; Steed, T.; Nguyen, T.; Futalan, D.; Akers, J.C.; Sarkaria, J.; Jiang, T.; Chowdhury, D.; et al. A genome-wide miRNA screen revealed miR-603 as a MGMTregulating miRNA in glioblastomas. Oncotarget 2014, 5, 4026-4039.

113. Chen, H.; Li, X.; Li, W.; Zheng, H. miR-130a can predict response to temozolomide in patients with glioblastoma multiforme, independently of O6-methylguanine-DNA methyltransferase. J. Transl. Med. 2015, 13, doi:10.1186/s12967-015-0435-y.

114. Yan, W.; Liu, Y.; Yang, P.; Whang, Z.; You, Y.; Jiang, T. MicroRNA profiling of Chinese primary glioblastoma reveals a temozolomide-chemoresistant subtype. Oncotarget 2015, 6, 11676-11682.

115. Jung, E.J.; Santarpia, L.; Kim, J.; Esteva, F.J.; Moretti, E.; Buzdar, A.U.; Di Leo, A.; Le, X.F.; Bast, R.C., Jr.; Park, S.T.; et al. Plasma microRNA 210 levels correlate with sensitivity to trastuzumab and tumor presence in breast cancer patients. Cancer 2012, 118, 2603-2614.

116. Svoboda, M.; Slyskova, J.; Schneiderova, M.; Makovicky, P.; Bielik, L.; Levy, M.; Lipska, L.; Hemmelova, B.; Kala, Z.; Protivankova, M.; et al. HOTAIR long non-coding RNA is a negative prognostic factor not only in primary tumors, but also in the blood of colorectal cancer patients. Carcinogenesis 2014, 35, 1510-1515.

117. Li, J.; Wang, Y.; Yu, J.; Dong, R.; Qiu, H. A high level of circulating HOTAIR is associated with progression and poor prognosis of cervical cancer. Tumour Biol. 2015, 36, 1661-1665.

118. Li, R.; Qian, J.; Wang, Y.Y.; Zhang, J.X.; You, Y.P. Long noncoding RNA profiles reveal three molecular subtypes in glioma. CNS Neurosci. Ther. 2014, 20, 339-343.

119. Wang, P.; Ren, Z.; Sun, P. Overexpression of the long non-coding RNA MEG3 impairs in vitro glioma cell proliferation. J. Cell. Biochem. 2012, 113, 1868-1874.

120. Chisholm, K.M.; Wan, Y.; Li, R.; Montgomery, K.D.; Chang, H.Y.; West, R.B. Detection of long non-coding RNA in archival tissue: Correlation with polycomb protein expression in primary and metastatic breast carcinoma. PLOS ONE 2012, 7, e47998.

121. Xu, N.; Chen, F.; Wang, F.; Lu, X.; Wang, X.; Lv, M.; Lu, C. Clinical significance of high expression of circulating serum lncRNA RP11-445H22.4 in breast cancer patients: A Chinese population-based study. Tumour Biol. 2015, PubMed ID 25929808. 
122. Zhu, S.; Si, M.L.; Wu, H.; Mo, Y.Y. MicroRNA-21 targets the tumor suppressor gene tropomyosin 1 (TPM1). J. Biol. Chem. 2007, 282, 14328-14336.

123. Wu, M.F.; Yang, J.; Xiang, T.; Shi, Y.Y.; Liu, L.J. miR-21 targets Fas ligand-mediated apoptosis in breast cancer cell line MCF-7. J. Huazhong Univ. Sci. Technologie Med. Sci. 2014, 34, 190-194.

124. Yan, L.X.; Wu, Q.N.; Zhang, Y.; Li, Y.Y.; Liao, D.Z.; Hou, J.H.; Fu, J.; Zeng, M.S.; Yun, J.P.; $\mathrm{Wu}$, Q.L.; et al. Knockdown of miR-21 in human breast cancer cell lines inhibits proliferation, in vitro migration and in vivo tumor growth. Breast Cancer Res. 2011, 13, R2.

125. Zhu, S.; Wu, H.; Wu, F.; Nie, D.; Sheng, S. Mo, Y.Y. MicroRNA-21 targets tumor suppressor genes in invasion and metastasis. Cell Res. 2008, 18, 350-359.

126. Selcuklu, S.D.; Donoghue, M.T.; Kerin. M.J.; Spillane, C. Regulatory interplay between miR-21, JAG1 and 17beta-estradiol (E2) in breast cancer cells. Biochem. Biophys. Res. Commun. 2012, 423, 234-239.

127. Song, B.; Wang, C.; Liu, J.; Wang, X.; Lv, L.; Wei, L.; Xie, L.; Zheng,Y.; Song, X. MicroRNA-21 regulates breast cancer invasion partly by targeting tissue inhibitor of metalloproteinase 3 expression. J. Exp. Clin. Cancer Res. 2010, 29, doi:10.1186/1756-9966-29-29.

128. Chen, Y.; Liu, W.; Chao, T.; Zhang, Y.; Yan, X.; Gong, Y.; Qiang, B.; Yuan, J.; Sun, M.; Peng, X. MicroRNA-21 down-regulates the expression of tumor suppressor PDCD4 in human glioblastoma cell T98G. Cancer Lett. 2008, 272, 197-205.

129. Schramedei, K.; Mörbt, N.; Pfeifer, G.; Läuter, J.; Rosolowski, M.; Tomm, J.M.; von Bergen, M.; Horn, F.; Brocke-Heidrich, K. MicroRNA-21 targets tumor suppressor genes ANP32A and SMARCA4. Oncogene 2011, 30, 2975-2985.

130. Papagiannakopoulos, T.; Shapiro, A.; Kosik, K.S. MicroRNA- 21 targets a network of key tumor-suppressive pathways in glioblastoma cells. Cancer Res. 2008, 68, 8164-8172.

131. Yang, C.H.; Pfeffer, S.R.; Sims, M.; Yue, J.; Wang, Y.; Linga, V.G.; Paulus, E.; Davidoff, A.M.; Pfeffer, L.M. The oncogenic microRNA-21 inhibits the tumor suppressive activity of FBXO11 to promote tumorigenesis. J. Biol. Chem. 2015, 290, 6037-6046.

132. Gabriely, G.; Würdinger, T.; Kesari, S.; Esau, C.C.; Burchard, J.; Linsley, P.S.; Krichevsky, A.M. MicroRNA 21 promotes glioma invasion by targeting matrix metalloproteinase regulators. Mol. Cell Biol. 2008, 28, 5369-5380.

133. Li, Y.; Li, W.; Yang, Y.; Lu, Y.; He, C.; Hu, G.; Liu, H.; Chen, J.; He, J.; Yu, H. MicroRNA-21 targets LRRFIP1 and contributes to VM-26 resistance in glioblastoma multiforme. Brain Res. 2009, 1286, 13-18.

134. Ke, J.; Zhao, Z.; Hong, S.H.; Bai, S.; He, Z.; Malik, F.; Xu, J.; Zhou, L.; Chen, W.; Wu, X.; et al. Role of microRNA221 in regulating normal mammary epithelial hierarchy and breast cancer stem-like cells. Oncotarget 2015, 6, 3709-3721.

135. Li, Y.; Liu, M.; Zhang, Y.; Han, C.; You, J.; Yang, J.; Cao, C.; Jiao, S. Effects of ARHI on breast cancer cell biological behavior regulated by microRNA-221. Tumour Biol. 2013, 34, 3545-3554.

136. Zhao, J.J.; Lin, J.; Yang, H.; Kong, W.; He, L.; Ma, X.; Coppola, D.; Cheng, J.Q. MicroRNA$221 / 222$ negatively regulates estrogen receptor alpha and is associated with tamoxifen resistance in breast cancer. J. Biol. Chem. 2008, 283, 31079-31086. 
137. Di Leva, G.; Gasparini, P.; Piovan, C.; Ngankeu, A.; Garofalo, M.; Taccioli, C.; Iorio, M.V.; Li, M.; Volinia, S.; Alder, H.; et al. MicroRNA cluster 221-222 and estrogen receptor alpha interactions in breastcancer. J. Natl. Cancer Inst. 2010, 102, 706-721.

138. Falkenberg, N.; Anastasov, N.; Schaub, A.; Radulovic, V.; Schmitt, M.; Magdolen, V.; Aubele, M. Secreted uPAR isoform 2 (uPAR7b) is a novel direct target of miR-221. Oncotarget 2015, 6, 8103-8114.

139. Stinson, S.; Lackner, M.R.; Adai, A.T.; Yu, N.; Kim, H.J.; O’Brien, C.; Spoerke, J.; Jhunjhunwala, S.; Boyd, Z.; Januario, T.; et al. TRPS1 targeting by miR-221/222 promotes the epithelial-to-mesenchymal transition in breast cancer. Sci. Signal. 2011, 4, ra41.

140. Hwang, M.S.; Yu, N.; Stinson, S.Y.; Yue, P.; Newman, R.J.; Allan, B.B.; Dornan, D. miR-221/222 targets adiponectin receptor 1 to promote the epithelial-to-mesenchymal transition in breast cancer. PLOS ONE 2013, 8, e66502.

141. Xie, Q.; Yan, Y.; Huang, Z.; Zhong, X.; Huang, L. MicroRNA-221 targeting PI3-K/Akt signaling axis induces cell proliferation and BCNU resistance in human glioblastoma. Neuropathology 2014, 34, 455-464.

142. Quintavalle, C.; Garofalo, M.; Zanca, C.; Romano, G.; Iaboni, M.; del Basso De Caro, M.; Martinez-Montero, J.C.; Incoronato, M.; Nuovo, G.; Croce, C.M.; et al. miR-221/222 overexpession in human glioblastoma increases invasiveness by targeting the protein phosphate PTP $\mu$. Oncogene 2011, 31, 858-868.

143. Hao, J.; Zhang, C.; Zhang, A.; Wang, K.; Jia, Z.; Wang, G.; Han, L.; Kang, C.; Pu, P. miR-221/222 is the regulator of $\mathrm{Cx} 43$ expression in human glioblastoma cells. Oncol. Rep. 2012, 27, 1504-1510.

144. Yang, F.; Wang, W.; Zhou, C.; Xi, W.; Yuan, L.; Chen, X.; Li, Y.; Yang, A.; Zhang, J.; Wang, T. MiR-221/222 promote human glioma cell invasion and angiogenesis by targeting TIMP2. Tumour Biol. 2015, 36, 3763-3773.

145. Ueda, R.; Kohanbash, G.; Sasaki, K.; Fujita, M.; Zhu, X.; Kastenhuber, E.R.; McDonald, H.A.; Potter, D.M.; Hamilton, R.L.; Lotze, M.T.; et al. Dicer-regulated microRNAs 222 and 339 promote resistance of cancer cells to cytotoxic T-lymphocytes by down-regulation of ICAM-1. Proc. Natl. Acad. Sci. USA 2009, 106, 10746-10751.

146. Shi, Y.; Luo, X.; Li, P.; Tan, J.; Wang, X.; Xiang, T.; Ren, G. miR-7-5p suppresses cell proliferation and induces apoptosis of breast cancer cells mainly by targeting REG $\gamma$. Cancer Lett. 2015, 358, 27-36.

147. Liu, Z.; Liu, Y.; Li, L.; Xu, Z.; Bi, B.; Wang, Y.; Li, J.Y. MiR-7-5p is frequently downregulated in glioblastoma microvasculature and inhibits vascular endothelial cell proliferation by targeting RAF1. Tumour Biol. 2014, 35, 10177-10184.

148. Sasayama, T.; Nishihara, M.; Kondoh, T.; Hosoda, K.; Kohmura, E. MicroRNA-10b is overexpressed in malignant glioma and associated with tumor invasive factors, uPAR and RhoC. Int. J. Cancer 2009, 125, 1407-1413.

149. Sun, L.; Yan, W.; Wang, Y.; Sun, G.; Luo, H.; ,Zhang, J.; Wang, X.; You, Y.; Yang, Z.; Liu, N. MicroRNA-10b induces glioma cell invasion by modulating MMP-14 and uPAR expression via HOXD10. Brain Res. 2011, 1389, 9-18. 
150. Mar-Aguilar, F.; Mendoza-Ramírez, J.A.; Malagón-Santiago, I.; Espino-Silva, P.K.; Ruiz-Flores, P.; Santuario-Facio, S.K.; Rodríguez-Padilla, C.; Reséndez-Pérez, D. Serum circulating microRNA profiling for identification of potential breast cancer biomarkers. Dis. Markers 2013, 34, 163-169.

151. Ahmad, A.; Sethi, S.; Chen, W.; Ali-Fehmi, R.; Mittal, S.; Sarkar, F.H. Up-regulation of microRNA-10b is associated with the development of breast cancer brain metastasis. Am. J. Transl. Res. 2014, 6, 384-390.

152. Ernst, A.; Campos, B.; Meier, J.; Devens, F.; Liesenberg, F.; Wolter, M.; Reifenberger, G.; Herold-Mende, C.; Lichter, P.; Radlwimmer, B. De-repression of CTGF via the miR-17-92 cluster upon differentiation of human glioblastoma spheroid cultures. Oncogene 2010, 29, 3411-3422.

153. Leung, C.M.; Chen, T.W.; Li, S.C.; Ho, M.R.; Hu, L.Y.; Liu, W.S.; Wu T.T.; Hsu, P.C.; Chang, H.T.; Tsai, K.W. MicroRNA expression profiles in human breast cancer cells after multifraction and single-dose radiation treatment. Oncol. Rep. 2014, 31, 2147-2156.

154. Chan, J.A.; Krichevsky, A.M.; Kosik, K.S. MicroRNA-21 is an antiapoptotic factor in human glioblastoma cells. Cancer Res. 2005, 65, 6029-6033.

155. Ng, E.K.; Li, R.; Shin, V.Y.; Jin, H.C.; Leung, C.P.; Ma, E.S.; Pang, R.; Chua, D.; Chu, K.M.; Law, W.L.; et al. Circulating microRNAs as specific biomarkers for breast cancer detection. PLOS ONE 2013, 8, e53141.

156. D’Urso, P.I.; D’Urso, O.F.; Storelli, C.; Mallardo, M.; Gianfreda, C.D.; Montinaro, A.; Cimmino, A.; Pietro, C.; Marsigliante, S. miR-155 is up-regulated in primary and secondary glioblastoma and promotes tumour growth by inhibiting GABA receptors. Int. J. Oncol. 2012, 41, 228-234.

157. Jiang, L.; Mao, P.; Song, L.; Wu, J.; Huang, J.; Lin, C.; Yuan, J.; Qu, L.; Cheng, S.Y.; Li, J. miR-182 as a prognostic marker for glioma progression and patient survival. Am. J. Pathol. 2010, 177, 29-38.

158. Chiang, C.H.; Hou, M.F.; Hung, W.C. Up-regulation of miR-182 by $\beta$-catenin in breast cancer increases tumorigenicity and invasiveness by targeting the matrix metalloproteinase inhibitor RECK. Biochim. Biophys. Acta 2013, 1830, 3067-3076.

(C) 2015 by the authors; licensee MDPI, Basel, Switzerland. This article is an open access article distributed under the terms and conditions of the Creative Commons Attribution license (http://creativecommons.org/licenses/by/4.0/). 